\title{
The Strategies and Methods of Contemporary Product Design Education
}

\section{in China}

\author{
Peng Minshi ${ }^{1}$, Xu Kaiqiang ${ }^{1}$ \\ ${ }^{1}$ Hubei University of Technology, Wuhan, Hubei, 430068, China
}

Keywords: Product design, Teaching methods, Innovative Design

\begin{abstract}
The product design is an important professional course in industrial design specialty and it is a comprehensive training and application of industrial design expertise knowledge for students. In the educational process, in order to train highly qualified personnel for industrial design, product design teaching should focus on cultivating students' innovative thinking. Teachers should use different training practices to enhance students' creative thinking and advance design capabilities, so that the product design teaching can achieve the goal to train socially useful talents. Based on the author's teaching and practical experience, this paper analyzes the current situation of product design education and designs a practical innovation system of product design course. The research results of this paper have some contributive significance to fully exercise the students' ability to design, comprehensively analyze and solve problems.
\end{abstract}

\section{Introduction}

Industrial design is a new discipline that integrates technology and art, which emphasizes full consideration of the relationship between technology and art. This makes technology and art integrated together and expresses them in the design process. As the most important element in industrial design, product design emphasizes technical issues in the design, such as the function, structure, materials and incrustation of industrial products. At the same time, it will integrate aesthetics, culture and other factors, so that the products can fully demonstrate the excellent physical properties and beautiful artistic features. Therefore, in the process of product design, the combination of technology and art has become the focus of industrial designers. In process of product development and design teaching, the problem of how to instill the idea to students and what ways to take to improve students' ability to design product has become the focus of product design teaching.

\section{The Status of Product Design Education in China}

Product design is different from other art designs and it is closely related to national science, technology and economic strength. Making a general survey of outstanding product designs in the world, we find that most of them are from developed countries, especially in Europe and North America, such as Sony and Samsung. Their previous designs give people a feeling that their products are attractive in price and quality, while now they create the best products with exquisite and delicate design style, which makes them occupy part of the high-end European market. Product design education in our country started late and made rapid progress. We pay particular attention to design education. Many designers pursue advanced studies in Europe and America and they are the backbone of the future design. Aside from designers studying abroad, can our industrial design education cultivate our own designers? Probability that our industrial designers have long been 
employed is very low. In recent years, the distrust to people majoring industrial design results in a low employment rate of industrial design graduates. For example, a company that engages in industrial design has about 70 people and there are only two or three people left in the enterprise until the second year. Others are all changed which means to be fired up. The administrator in the company said: "we recruit three batches of industrial design graduate students and dismiss three batches." Faced with this severe reality, we should look for reasons from our own level of design education and we must recognize that there is a wide gap of design education level between China and other developed countries. In the design education, we attach importance to the concept and performance and the practice is not enough. As you know, we will face many practical problems in the conversion from students to career designers. The traditional way of education will only make students helpless when they face the complicated design situation. In Germany, students' design model capabilities are strong and they often have a good understanding and grasp of spatial morphology and mechanical structures. Chinese design students are generally ignorant about how the drawings transform into products. This shows that Chinese design students actually have a very good concept of design drawings, a high-quality design attainment and design theory and they lack practical innovation on the real conversion of products. Therefore, there are no good and excellent products for our designers. Practice has always been the sole criterion for testing truth. The design community in Chinese Mainland has not gained awards or been on the design yearbook. Therefore, we are really unqualified to say that there are many excellent product designers in China.

\section{The Construction of Classroom Practice Innovative System of Product Design}

Teaching content. In the teaching content, first we must strive to develop resource materials and teachers should be able to effectively expand content based on textbook content. Specifically, for some teaching materials, teachers should give some meaningful design cases to explain them. Although the case teaching method has always been used in design courses, the amount of content is not enough. Teachers should carry out teaching work with the basis of textbooks and the most advanced and real cases.

Practice teaching process. Practice teaching process roughly encompasses several aspects in a nutshell. First, we must teach the basic knowledge of the course. After the end of the course, most students have mastered the basic concepts and the knowledge of design. That is to say they are beginner. If teachers want to further improve students' comprehensive ability, they should give 2 to 3 weeks design classes. During this time, teachers can set some moderately difficult design subjects, give design books and make a simple explanation of each topic. It requires students to find information, choose materials, prepare design procedures and conduct analogue simulation based on their own ideas. It also asks students not to trap into books and demands them to let go of ideas and optimize the existing programs. Teachers should encourage students to complete the design with the simplest design and lowest cost. After personal design is successful, this student should be required to complete the detailed design report and design experience. Such practice process cultivates students' ability to innovate, develop independently and apply comprehensively. It is a bold attempt for design education reform.

\section{Several Key Points that Need to Pay Close Attention to}

Integrate the latest knowledge into teaching. In the teaching process, teachers should give students timely additional knowledge about innovative design except for traditional courses, including the latest development trend in the design discipline and knowledge of some advanced 
industrial mechanical design software. The integration of the latest knowledge will make classroom teaching more modern in terms of teaching methods, so that students can intuitively understand knowledge of industrial design. That plays an important role in practical operation.

Adopt multi-dimensional interactive teaching and inquiry-based discussions. The so-called multi-dimensional interactive teaching is to make students exploring design according to their talents and interests through discussion and inquiry. When carrying out this type of teaching, teachers should conduct practical engineering technical innovation which is combined with the scope and focus of the learning knowledge. In the design program discussion, they should encourage students to break conventions and propose innovative, logical, rational and practical designs. Teachers should remember not to easily deny students. They may well conduct correct education and encourage students to improve programs continuously to make it more mature.

Actively carry out innovative practical training and improve students' innovative ability. Recently, a number of product design experts of industrial design specialty in universities and product design students of Zhuhai College of Beijing Institute of Technology conducted a discussion on the gap between vocational skills and actual business requirements. Experts all agree that our country still lacks product design talents, but most companies do not want to recruit graduates majoring product design. The reason is that the theory and practice in higher education come apart. Students' professional skills have flaws and their experience is quite scarce. Under the new situation, it is difficult for the traditional textbook-based teaching method to achieve the teaching purpose and we should replace the course teaching with design training. That means we should use topics from the easier to the more advanced to teach knowledge of organic system design to students in a systematic way. That will enable them to digest and absorb knowledge in advancing the process of the subject in order to achieve the purpose of improving students' creativity. Although such subject training in university education has also been tried, it is still limited to a fraction of students and postgraduates. The collective subject teaching in the university education in China is still a blank. It needs to affirm that these series of design projects are not necessarily the actual designs and it can be teaching projects based on design procedures and methodology. These teaching projects not only emphasize the organic links with relative knowledge, but also pay attention to the continuity and integrity of the design process, especially practical aspects, including market research, modeling, engineering design and marketing.

\section{Specific Measures to Implement the Reform of Practice Teaching Classroom}

To confirm the educational goal and adjust the teaching structure. Industrial design is a discipline that services society with intelligence and its foothold is the business service. Designers' designs become products through the operation of enterprises, which will benefit mankind. Therefore, in terms of the educational objective of the industrial design, it must base on the innovative practice teaching and provide space for students to discuss and practice innovation. In the reform of practice teaching classroom, educators should adjust the teaching structure. They should carry out teaching structure adjustment with highlighting practice teaching and overall consideration to enable enterprises to get the maximum profit.

Understand the Business Needs of the Industrial Design Expertise. The design discipline advances with the times and design content has a doughty variability. Industrial design takes science and technology as its guide direction and the most excellent industrial design should serve the business. In the teaching process, teachers should know the business needs of the industrial design expertise and design practice teaching content based on the needs of the most companies in our country. They will keep abreast of requirements of business knowledge structure and ability for 
designers, so teachers can purposefully guide students to strengthen the training for weak links to meet the practical needs in work.

Strengthen practice to enhance students' social awareness and ability to meet the needs of society. To have better jobs, we should have the basic social consciousness and ability to adapt to society. In the classroom teaching, teachers should pay attention to the cultivation of students' social consciousness and attach importance to strengthening the practice teaching. From the view of requirements for practitioners in design, it is apparent that the introduction of practice teaching into product teaching in design industry can give full play to the core course of product design. That plays an important role in guiding the development of product design and provides strong support for the future development of industrial design disciplines.

\section{Conclusion}

As international competition intensifies, the industrial market puts forward new requirements for design talents. The current training system and teaching content cannot adapt to this new situation. In order to change this education status, we should pay attention to the cultivation of students' practical ability and the improvement of their overall quality. We should transform virtual projects teaching to practical project teaching in product design and continue to extend classroom teaching. This emphasizes that design practice teaching is the target purpose to cultivate and improve students' ability to innovate and apply knowledge to solve practical problems.

\section{Reference}

[1] Jin Chengyu. The Teaching Practice of Product Design [J]. China Science and Technology Information, 2009, 10: 256-257.

[2] Zhang Yanping, Fu Zhiguo. A Research on Teaching Reform of Product Design [J]. Journal of Mudanjiang College of Education, 2008, 03: 122-123.

[3] Wang Xin. A Research on Teaching and Practical Innovation of Product Design [J]. Continue Education Research, 2010, 11: 137-138.

[4] Li Jun. A Reflection on Product Design Teaching [J]. Arts Education, 2011, 01: 15.

[5] Liu Ping. A Research on Flipped Classroom Teaching of Product Design [J]. Journal of Hunan Tax College, 2015, 06: 86-88.

[6] Fan Jing. A Research on the Combination of Product Design Teaching and Interactive Design [J]. Design, 2015, 05: 145-146. 